\title{
Effects of nifedipine on fetal pulmonary blood flow in preterm labor
}

\author{
Şule Göncü Ayhan (iD, Deniz Oluklu (D), Eda Özden Tokalıŏlu (iD, Dilek Şahin \\ Perinatology Clinic, Ankara City Hospital, Ankara, Turkey
}

\begin{abstract}
Objective: To determine the effect of nifedipine on the fetal pulmonary system by acceleration/ejection time ratio of the fetal main pulmonary artery Doppler waveform.

Methods: This prospective study was conducted in a high-risk pregnancy clinic with pregnant women who required nifedipine treatment to prevent preterm labor between 24 and 34 weeks of gestation. An ultrasound examination that included measurements of the acceleration time (AT), ejection time (ET), and AT/ET ratio (PATET) were performed before and $48 \mathrm{~h}$ after the first nifedipine dose.

Results: Forty-three pregnant women were included in this study. AT and PATET found higher in the after nifedipine group when compared with before nifedipine group. When the ET parameters were compared, no differences were detected between the groups.

Conclusion: Nifedipine increases fetal pulmonary blood flow which appears to increase AT and PATET on Doppler parameters in pregnant women with preterm labor after $48 \mathrm{~h}$ treatment.
\end{abstract}

Keywords: Nifedipine, preterm labor, fetal pulmonary artery, Doppler, ultrasound.

\section{Introduction}

Despite the rapid development of medicine in the last decades, preterm labor and prematurity still remain the leading cause of perinatal morbidity and mortality. One of the most preferred tocolytic agents is calcium channel blockers, especially nifedipine in the management of preterm labor (PTL). ${ }^{[1]}$ Nifedipine is used orally and provides a relaxation on smooth muscles. ${ }^{[1,2]}$ Besides the advantages of this relaxation effect on uterine muscles,

\section{Özet: Preterm doğumda nifedipinin fetal pulmoner kan akışına etkisi}

Amaç: Fetal ana pulmoner arter Doppler dalga formunun hızlanma/ejeksiyon zamanı oranıla nifedipinin fetal pulmoner sistem üzerindeki etkisini belirlemek.

Yöntem: Bu prospektif çalışma, bir yüksek riskli gebelik kliniğinde gebeliğin 24 ile 34. haftaları arasında preterm doğumu önlemek için nifedipin tedavisine ihtiyaç duyan gebelerle gerçekleştirildi. İlk nifedipin dozundan önce ve 48 saat sonrasında hızlanma zamanı (AT), ejeksiyon zamanı (ET) ve AT/ET oranı (PATET) ölçümlerini içeren bir ultrason muayenesi yapıldı.

Bulgular: Bu çalışmaya 43 gebe dahil edildi. AT ve PATET değerleri, nifedipin öncesi gruba kıyasla nifedipin sonrası grupta daha yüksek bulundu. ET parametreleri karşılaştırıldığında, gruplar arasında hiçbir farklılık bulunmadı.

Sonuç: Nifedipin fetal pulmoner kan akışını artırmaktadır ve bu da, 48 saatlik tedavi sonrasında preterm doğum yapan gebelerde Doppler parametrelerindeki AT ve PATET değerlerini artırmaktadır.

Anahtar sözcükler: Nifedipin, preterm doğum, fetal pulmoner arter, Doppler, ultrason.

the drug has also potential side effects on the vascular system for both mother and fetus. ${ }^{[3,4]}$

Pulmonary artery Doppler is a non-invasive tool that drew attention to respiratory complication prediction in preterm neonates recently. ${ }^{[5] 7}$ Pulmonary arterial pressure and impedance alterations reflect on Doppler parameters of the fetal pulmonary artery. ${ }^{[8,9]}$ Therefore, the relaxation effect of nifedipine may affect fetal pulmonary circulation. 
In this study, our aim was to evaluate the effects of nifedipine on the fetal pulmonary system by using fetal pulmonary artery Doppler parameters.

\section{Methods}

This prospective study was conducted between February 1 and April 30, 2021 in the High-Risk Pregnancy Clinic of Turkish Ministry of Health Ankara City Hospital. Pregnant women who required nifedipine treatment to prevent preterm labor between 24 and 34 weeks of gestation were included in the study. Written informed consent was obtained from all participants. The protocol was approved by the Medical Research Ethics Department of the Hospital (no: E2-21-80, January 21, 2021). Both target alpha $(\alpha)$ and beta $(\beta)$ error levels were considered 0.05 to obtain $95 \%$ power and the minimum required number was calculated 39.

Preterm labor was defined as persistent uterine contractions (at least two contractions in 10 min or four contractions in $1 \mathrm{~h}$ ) resulting in changes in the cervix (minimum $80 \%$ effacement and $2 \mathrm{~cm}$ cervical dilatation). ${ }^{[10]}$ The women known to have multifetal pregnancies, fetal structural anomalies, preterm premature rupture of the membranes, fetal growth restriction, any contraindication for maternal nifedipine administration, severe maternal hypotension or tachycardia during nifedipine therapy, and maternal systemic diseases were excluded.

Nifedipine was administered orally with a loading dose of $10 \mathrm{mg}$ every $20 \mathrm{~min}$ for the first hour, and maintained at $10 \mathrm{mg}$ every $6 \mathrm{~h}$ for the first $48 \mathrm{~h}$, totally $80 \mathrm{mg}$. Doppler measurements were performed before and $48 \mathrm{~h}$ after the first nifedipine dose. $12 \mathrm{mg}$ intramuscular betamethasone was administered to all pregnant women two times, 24 hours apart.

The last menstrual period or first-trimester crownrump length was used to determine gestational age. Doppler measurements were performed between 24 and 34 weeks of gestation by the same maternal-fetal medicine specialist using software of GE Voluson E8 Ultrasound machine (GE Healthcare Systems, Chicago, IL, USA) C2-9 convex probe (3-9 Mhz). Patients were examined in a semi-Fowler position to avoid orthostatic hypotension. The fetal cardiac four-chamber view was obtained first. Then by rotating the transducer to the short-axis view, the fetal main pulmonary artery (MPA) was visualized. At the proximal portion of the MPA, pul- monary valves and the bifurcation of the pulmonary artery were identified. The sample volume gate was adjusted to $3 \mathrm{~mm}$ and positioned between the valves and the bifurcation. Acceleration time (AT) and ejection time (ET) measurements were done by manual trace when a specific MPA Doppler pattern was obtained. ${ }^{[1]}$ AT is the time interval from the onset of flow to the maximum flow of the peak systolic velocity and ET is the time interval from the beginning to the end of ventricular systole. The pulmonary artery ratio (PATET) was calculated as follows: AT/ET.

Doppler measurements were performed before and $48 \mathrm{~h}$ after the first nifedipine dose.

Initial Doppler measurements were performed before betamethasone admission.

Maternal vital signs (blood pressure, pulse) were followed during nifedipine therapy and noted in the normal range. In the presence of maternal hypotension or tachycardia, nifedipine was not given for maintenance, and the patient was excluded from the study.

SPSS 17 (SPSS Inc., Chicago, Il, USA) was used for statistical analysis. The Shapiro-Wilk test, KolmogorovSmirnov test were used to determine the distribution of normality. The continuous variables were presented as mean and standard deviations. Groups were compared with the paired Sample t-test for normally distributed variables and with the Wilcoxon signed rank test for not normally distributed variables. A type- 1 error below 0.05 was considered statistically significant.

\section{Results}

Forty-three pregnant women were included in the present study. The demographic characteristics of the patients were given in Table 1.

When the AT, ET and, PATET parameters were compared before and after the nifedipine treatment, AT and PATET displayed increased values in the after nifedipine group (AN) compared to the before nifedipine group (BN). When the ET was compared, no differences were detected between the groups. Table 2 provides a summary of fetal pulmonary Doppler parameters.

Of 43 patients, 18 were delivered after one week period. The mean gestational age (GA) of this group was 34 weeks and the mean estimated fetal weight (EFW) 
Table 1. Demographic data.

\begin{tabular}{lccc} 
& Mean/Median & SD $( \pm)$ & (Min-Max) \\
\hline Age & $27.5 / 27$ & 4.9 & $18-36$ \\
\hline Gravidity & $1.8 / 2$ & 0.8 & $1-4$ \\
\hline Parity & $0.5 / 0$ & 0.1 & $0-2$ \\
\hline Week of gestation & $32.8 / 33$ & 0.8 & $31-34$ \\
\hline Body mass index $\left(\mathrm{kg} / \mathrm{m}^{2}\right)$ & $28.5 / 27$ & 7.1 & $20-44$ \\
\hline
\end{tabular}

was $2184 \mathrm{~g}$. There were 4 neonatal intensive care unit (NICU) admissions in this group. For the other 25 pregnant women discharged after treatment, the mean GA for delivery was 37 weeks and the mean EFW was $2860 \mathrm{~g}$. There was no neonatal morbidity or mortality observed in this group.

\section{Discussion}

In the present study, higher AT values and PATET ratios were found in the AN group in MPA when compared to the $\mathrm{BN}$ group, while ET values did not change with nifedipine admission.

In the past, neonates were examined for RDS evaluation with pulmonary artery Doppler, and when mean pulmonary artery pressure increases, AT time becomes shorter because peak velocity is maximized at the early systole. ${ }^{[12]}$ Starting from this point, several studies were conducted with fetal pulmonary artery Doppler for fetal pulmonary maturity evaluation and neonatal RDS prediction. Schenone et al. found increased PATET values with increased gestational age, and also, correlates by amniocentesis with testing fetal lung maturity. ${ }^{[13]}$ This result is consistent with increased wall elasticity in the pulmonary artery due to the lung maturation process. Guan et. al. found that, even after controlling for gestational age, the AT values and PATET ratios were significantly lower in the RDS group than in the non-RDS group. ${ }^{[6]}$ Therefore,
ET is a more non-variable parameter and reported that did not change throughout gestation. ${ }^{[6,7]}$ In the present study, ET was similar before and after nifedipine treatment.

Nifedipine is a potent cardiovascular drug that diminishes smooth muscle contractility and results in arterial relaxation in vascular tissue. ${ }^{[3]}$ Additionally, nifedipine crosses the placenta with a maternal/fetal plasma ratio of $0.93 .^{[14]}$ It is possible to affect fetal pulmonary circulation by the same mechanism of action. Consistent with this theory, increased AT which means increased blood flow in the fetal pulmonary artery was observed after nifedipine treatment.

Yllmaz and Göncü reported that no significant changes occur in fetal circulation and fetal cardiac parameters after $48 \mathrm{~h}$ nifedipine treatment. ${ }^{[4]}$ In another study, maternal and fetal hemodynamics were evaluated after nifedipine treatment and despite significant maternal changes, they could not find any changes in uterine, umbilical, or middle cerebral artery blood flow. ${ }^{[15]}$ In both of these studies, fetal circulation was evaluated with pulsatility index (PI) to investigate blood flow resistance, and pulmonary artery Doppler did not include as a study parameter. Furthermore, AT and ET are time-based measurements, and especially AT was reported as the best variable correlates with pulmonary resistance. ${ }^{[16,17]}$ That is why we chose these parameters to evaluate fetal pulmonary flow alterations.

Table 2. Fetal pulmonary artery Doppler parameters.

\begin{tabular}{lccc} 
& Before nifedipine (Mean \pm SD) & After nifedipine (Mean \pm SD) & p-value \\
AT & $57.2 \pm 9.8$ & $59.2 \pm 9.6$ & $0.001^{*}$ \\
\hline ET & $215.1 \pm 35.8$ & $214.6 \pm 38$ & $0.80^{*}$ \\
\hline PATET & $0.27 \pm 0.06$ & $0.29 \pm 0.07$ & $0.001^{\dagger}$ \\
\hline
\end{tabular}

*Wilcoxon signed rank test; †Paired sample t test. AT: acceleration time; ET: ejection time; PATET: AT/ET. 
Antenatal steroid therapy improves fetal lung maturity in high-risk pregnant women for preterm delivery, but the actual mechanism is still not clear ${ }^{[18]}$ Lindsley et al. found decreased pulmonary artery AT values in fetuses treated with corticosteroids when compared with controls. ${ }^{[19]}$ Another study reported that steroid admission did not alter pulmonary blood flow when fetuses were examined with pulmonary artery Doppler before and after betamethasone administration. ${ }^{[20]}$ In our study, all pregnant women received betamethasone after initial Doppler evaluation for fetal pulmonary maturation in addition to nifedipine, and AT increased after treatment. The main reason for this result seems to be related with nifedipine's vasorelaxation effect rather than betamethasone's.

The main strengths of the present study were its novelty and prospective design. The main limitations were the relatively low number of participants and two drug administrations at the same time.

\section{Conclusion}

Nifedipine increases fetal pulmonary blood flow which appears to increase AT and PATET on Doppler parameters in pregnant women with preterm labor after $48 \mathrm{~h}$ treatment. To date, there is no data in the literature about this issue. Further researches with larger numbers of patients are necessary to validate these results.

\section{Acknowledgment}

The authors give special thanks to all the healthcare staff who works at the high-risk pregnancy clinic.

Funding: This work did not receive any specific grant from funding agencies in the public, commercial, or not-for-profit sectors.

Compliance with Ethical Standards: The authors stated that the standards regarding research and publication ethics, the Personal Data Protection Law and the copyright regulations applicable to intellectual and artistic works are complied with and there is no conflict of interest.

\section{References}

1. King JF, Flenady VJ, Papatsonis DN, Dekker GA, Carbonne B. Calcium channel blockers for inhibiting preterm labour. Cochrane Database Syst Rev 2003;(1):CD002255. [PubMed] [CrossRef]

2. Gáspár R, Hajagos-Tóth J. Calcium channel blockers as tocolytics: principles of their actions, adverse effects and thera- peutic combinations. Pharmaceuticals (Basel) 2013;6:689-99. [PubMed] [CrossRef]

3. Oei SG. Calcium channel blockers for tocolysis: a review of their role and safety following reports of serious adverse events. Eur J Obstet Gynecol Reprod Biol 2006;126:137-45. [PubMed] [CrossRef]

4. Yılmaz O, Göncü AŞ. Effects of nifedipine on fetal cardiac function in preterm labor. J Perinat Med 2020;48:723-7. [PubMed] [CrossRef]

5. Yamamoto Y, Hirose A, Jain V, Hornberger LK. Branch pulmonary artery Doppler parameters predict early survival-nonsurvival in premature rupture of membranes. J Perinatol 2020; 40:1821-7. [PubMed] [CrossRef]

6. Guan Y, Li S, Luo G, Wang C, Norwitz ER, Fu Q, et. al. The role of doppler waveforms in the fetal main pulmonary artery in the prediction of neonatal respiratory distress syndrome. J Clin Ultrasound 2015;43:375-83. [PubMed] [CrossRef]

7. Chaoui R, Taddei F, Rizzo G, Bast C, Lenz F, Bollmann R. Doppler echocardiography of the main stems of the pulmonary arteries in the normal human fetus. Ultrasound Obstet Gynecol 1998;11:173-9. [PubMed] [CrossRef]

8. Büke B, Destegül E, Akkaya H, Şimşek D, Kazandi M. Prediction of neonatal respiratory distress syndrome via pulmonary artery Doppler examination. J Matern Fetal Neonatal Med 2019;32:1640-5. [PubMed] [CrossRef]

9. Goncu SA, Atalay A, Sinaci S, Tanacan A, Tokatloglu OE, Oluklu D, et al. Effects of SARS-COV-2 infection on fetal pulmonary artery Doppler parameters. Echocardiography 2021 Jun 29. Online ahead of print. [PubMed] [CrossRef]

10. American College of Obstetricians and Gynecologists' Committee on Practice Bulletins-Obstetrics. Practice bulletin No. 171: management of preterm labor. Obstet Gynecol 2016; 128:e155-64. [PubMed] [CrossRef]

11. Azpurua H, Norwitz ER, Campbell KH, Funai EF, Pettker $\mathrm{CM}$, Kleine $\mathrm{M}$, et al. Acceleration/ejection time ratio in the fetal pulmonary artery predicts fetal lung maturity. Am J Obstet Gynecol 2010;203:40.e1-8. [PubMed] [CrossRef]

12. Kitabatake A, Inoue M, Asao M, Masuyama T, Tanouchi J, Morita T, et al. Noninvasive evaluation of pulmonary hypertension by a pulsed Doppler technique. Circulation 1983;68: 302-9. [PubMed] [CrossRef]

13. Schenone MH, Samson JE, Jenkins L, Suhag A, Mari G. Predicting fetal lung maturity using the fetal pulmonary artery Doppler wave acceleration/ejection time ratio. Fetal Diagn Ther 2014;36:208-14. [PubMed] [CrossRef]

14. Pirhonen JP, Erkkola RU, Ekblad UU, Nyman L. Single dose of nifedipine in normotensive pregnancy: nifedipine concentrations, hemodynamic responses, and uterine and fetal flow velocity waveforms. Obstet Gynecol 1990;76(5 Pt 1):807-11. [PubMed] [CrossRef]

15. Cornette J, Duvekot JJ, Roos-Hesselink JW, Hop WC, Steegers EA. Maternal and fetal haemodynamic effects of 
nifedipine in normotensive pregnant women. BJOG 2011;118: 510-40. [PubMed] [CrossRef]

16. Martin-Duran R, Larman M, Trugeda A, Vazquez de Prada JA, Ruano J, Torres A, et al. Comparison of Doppler-determined elevated pulmonary arterial pressure with pressure measured at cardiac catheterization. Am J Cardiol 1986;57:859-63. [PubMed] [CrossRef]

17. Sosa-Olavarria A, Zurita-Peralta J, Schenone CV, Schenone $\mathrm{MH}$, Prieto F. Doppler evaluation of the fetal pulmonary artery pressure. J Perinat Med 2019;47:218-21. [PubMed] [CrossRef]

18. Roberts D, Brown J, Medley N, Dalziel SR. Antenatal corticosteroids for accelerating fetal lung maturation for women at risk of preterm birth. Cochrane Database Syst Rev 2017;3(3): CD004454. Update in: Cochrane Database Syst Rev 2020; 12(12):CD004454. [PubMed] [CrossRef]

19. Lindsley W, Hale R, Spear A, Adusumalli J, Singh J, DeStefano $\mathrm{K}$, et al. Does corticosteroid therapy impact fetal pulmonary artery blood flow in women at risk for preterm birth? Med Ultrason 2015;17:280-3. [PubMed] [CrossRef]

20. Güngör ES, İlhan G, Gültekin H, Zebitay AG, Cömert S, Verit FF. Effect of betamethasone on fetal pulmonary and umbilical artery Doppler velocimetry and relationship with respiratory distress syndrome development. J Ultrasound Med 2017;36:2441-5. [PubMed] [CrossRef]

This work is licensed under the Creative Commons Attribution-NonCommercial-NoDerivs 4.0 Unported (CC BY-NC-ND4.0) License. To view a copy of this license, visit http://creativecommons.org/licenses/by-nc-nd/4.0/ or send a letter to Creative Commons, PO Box 1866, Mountain View, CA 94042 , USA.

Publisher's Note: The content of this publication does not necessarily reflect the views or policies of the publisher, nor does any mention of trade names, commercial products, or organizations imply endorsement by the publisher. Scientific and legal responsibilities of published manuscript belong to their author(s). The publisher remains neutral with regard to jurisdictional claims in published maps and institutional affiliations. 